European journal of American studies

Special Issue: Women in the USA

\title{
Afro-American Women Activists as True Negotiators in the International Arena (1893-1945)
}

Fatma Ramdani

\section{(2) OpenEdition}

\section{Journals}

Electronic version

URL: https://journals.openedition.org/ejas/10646

DOI: 10.4000/ejas. 10646

ISSN: 1991-9336

Publisher

European Association for American Studies

\section{Electronic reference}

Fatma Ramdani, "Afro-American Women Activists as True Negotiators in the International Arena (1893-1945)", European journal of American studies [Online], 10-1 | 2015, document 1.8, Online since 26 March 2015, connection on 08 July 2021. URL: http://journals.openedition.org/ejas/10646 ; DOI: https://doi.org/10.4000/ejas. 10646

This text was automatically generated on 8 July 2021.

Creative Commons License 


\title{
Afro-American Women Activists as True Negotiators in the International Arena (1893-1945)
}

\author{
Fatma Ramdani
}

\author{
"We must remake the world. The task is \\ nothing less than that". \\ (Mary McLeod Bethune, World Assembly for \\ Moral Re-Armament in Caux, Switzerland, July \\ $27,1954)$
}

\section{Introduction}

1 Starting from the mid-19 $9^{\text {th }}$ century, Afro-American women used the international stage as a protest and advocacy tool to attract world attention on the race problem in the United States and on the limits of American democracy. The slavery period, then the post-bellum era and the two world conflicts all marked crucial steps in American black women's mobilization on the international front. Aiming for progress, AfroAmerican women's diligent and relentless mobilization within and across borders transformed them into true negotiators and mediators on the international arena. Black women activists rooted their demand for racial justice in the ideals of American democracy as embodied in American documents from the Constitution to the Emancipation proclamation.

2 This article seeks to shed some light on the overlooked influence Afro-American women had in international world politics from the late nineteenth century to the midtwentieth century. Since Afro-American women were caught in the middle of race and gender conflicts, they had acute perceptions of justice issues, and thus embarked in changing the world. After a review of the historical perspective of the national and international contexts which prompted Afro-American women to turn to international activism, I will explain how their involvement in more global movements, like the Pan- 
African and international feminist and peace movements, developed their expertise of the public sphere and of international issues. The second part of the article seeks to offer a more comprehensive vision of the true involvement of Afro-American women in the peace-building process and human-rights agenda. It will give an overview of the numerous activities launched by Afro-American women leaders through the organizations they founded and it analyzes the actions of some of their key leaders as well as their discourses. It will show how these black women leaders linked their national political struggle for freedom and liberty to the conditions of people of color throughout the world and acted as informal diplomats in the international arena. Lastly, I will discuss the extent to which we can consider that these black women leaders paved the way for the new diplomacy methods of the $21^{\text {st }}$ century. Mary McLeod Bethune and Amy Jacques Garvey's transnational concerns and long-term lobbying strategies will be used to illustrate the pioneering role black women leaders played in terms of international agenda-setting. As non-state actors trying to shape U.S. foreign policy, Afro-American women leaders from the early twentieth century can be considered to be inspirational models for the post-Cold War approach to diplomacy.

\section{Historical perspective of Black women's internationalism}

3 Afro-American women are now acknowledged to have been the traditional leaders of the black resistance movement. ${ }^{i}$ Yet, their contribution to US foreign policy before the Cold War period as peace and human rights advocates needs to be further investigated. As a step towards rectifying this oversight, this article examines the trajectories and the achievements of black women leaders, such as Ida Barnett Wells, Mary Church Terrell, Addie Hunton, Amy Jacques Garvey and Mary McLeod Bethune. When we look at their involvement across time and space, their multidimensional and multi-layered mobilization across borders is impressive. Because of their particular status, their "greatest known handicap" of "Being a Negro and a Negro Woman"ii living in the United States, Afro-American women seized all opportunities to make their voices heard. They consequently became actively involved in different movements: the black movement, the women and feminist peace movements. They acted as bridges between these different movements and launched key initiatives that are studied further. As such, we can argue that Afro-American women were the political vanguards for formal and informal networking within the black communities, women and peace movements. In particular, they attended the international conferences organized by these different movements. These gatherings gave Afro-American women activists new opportunities to "define themselves before an international audience and to voice their demands for political, social and economic justice in the United States." iii

4 One aspect which is worth mentioning is that the race women leaders discussed in this article shared a common point: they all linked their international activism to the racism they experienced in the United States. Mostly educated women ${ }^{\text {iv }}$ and imbued with the ideology of Victorian womanhood, they endorsed the notion of women's higher capacity. As socially responsible individuals, these black women activists felt vested with the responsibility to uplift their race and develop a better society.v 


\subsection{The national context}

5 On the national level, Afro-American women's activism in the abolitionist movement marked the starting point of their political commitment. ${ }^{\text {vi }}$ The post-bellum era marked a second step in Afro-American involvement on the international stage. Indeed, the end of slavery did not solve the issue of racism in the United States. Jim Crow politics, with its violence against black Americans and its brutal lynchings, the abusive convict lease and the peonage systems, the repeated dehumanizing attacks on trains were some of the many examples of the blatant policy of persecution and injustice perpetrated upon the people of color of the United States, in particular in the South. Just like their antebellum sisters (Harriet Tubman, the abolitionist activist or Frances E. W Harper, the abolitionist writer), Afro-American women activists wanted to secure the rights their community had been denied. They were determined to invest the public space with the view of ending racial oppression in the United States, while advancing their specific gendered perspective. It was time for action, to look for the solution to the race problem. Afro-American women became unhesitatingly involved in black organizations, like the National Association for the Advancement of Colored People (NAACP) founded in 1909, or the UNIA, the Universal Negro Improvement Association launched by Marcus Garvey in 1914. Their involvement in the Pan-African movement (as fund raisers, lecturers, pamphlet writers) shaped the development of the movement. Marcus Garvey considered black women as the stalwarts of the organization and the backbone of its local divisions. ${ }^{\text {vii }}$

6 Both the NAACP and the UNIA united around the Pan-African cause. Pan-African consciousness was seen as central to securing world peace and black freedom at a time when American imperialism and European colonialism had created a scientific race hierarchy. As examine in the second part of this article, Afro-American women's relentless activities within the black movement transformed them into experts on the race issue and helped them acquire important knowledge of international issues. In particular, their travels abroad to publicize the terrible Afro-American plight in the international arena helped them link racism in America with larger global processes of racism, imperialism and decolonization. ${ }^{\text {viii }}$ Within the Pan-African movement, they developed a strong understanding of the link between US domestic racism and colonial and neo-colonial control of people of color. They started theorizing about the connection between race/imperialism, justice and global peace. While lecturing on platforms abroad, they started articulating pioneering discourses on decolonization and human rights. Ida B. Wells, ${ }^{\mathrm{i}}$ as one of the most outspoken and original social critics of her day, illustrates this argument. As a leading voice in the civil rights protest in the 1890s and pan-African member, ${ }^{\mathrm{x}}$ Ida B. Wells launched key international initiatives which can help us determine black women's real influence in the shaping of US and foreign politics. After the lynching of her friend Thomas Moss in March 1892, Ida B. Wells started her worldwide campaign against lynching. After she had been invited by the English Quaker, Catherine Impey, a leading proponent of "the brotherhood of mankind irrespective of colour or descent," she toured England twice for more than a total of six months in 1893 and 1894 to appeal "to English people to aid us (=Blacks) in molding American public sentiment in favor of justice to everyone and a fair trial for life and liberty," with the view of putting "a stop to America's disgrace."xi Her many lectures on the inside story of lynching in America and the resolutions she crafted together with the international press coverage of her conferences sought to show the 
world America's faults. ${ }^{\text {xii }}$ Ida B. Wells's objective was to have Britain exert influence on civilized nations so that they could acknowledge their duty to fight against, what she called, the lynching evil and push America to remedy her failures. Her campaign in England had an impact as the 1893 record of lynching showed a decline and never increased after then. ${ }^{\text {xiii }}$ It also cemented her engagement to internationalism.

7 Shortly after her return from England, Ida B. Wells went straight to Chicago to mobilize black women to raise funds so that they could issue a pamphlet "The Reasons Why the Colored American Is Not In The World's Columbian Exposition", the World's Fair held in Chicago in 1893. Building upon the efficiency of her British campaign, she was even more determined to reveal to the world the race problem in America. Ten thousand copies of the pamphlet were circulated during the three months of the exhibition. Ida B. Wells explains in her autobiography that "every day I was on duty at the Haitian building, where Mr Douglass gave me a desk and spent the days putting the pamphlet in the hands of foreigners." ${ }^{\text {xiv }}$

8 It can be asserted that because of their experience as black women living in the USA, Afro-American women leaders had a special understanding of issues of justice and equality. As international Pan-African activists, they built their vision of a safe world on the abolition of the idea of innate race inferiority. Their shrewd analysis of America's deceptive "separate but equal" doctrine and of the imperialism of Western countries and institutionalized racism throughout the world, gave vent to new claims and strategies.

\subsection{The international context}

9 On the international level, the outbreak of World War I marked a new turning point in Afro-American racial consciousness and gave a new dimension to their mobilization for their political and civil rights. While President Wilson justified the entrance of the United States in the first World War conflict in April 1917 by stating that the US as "a free nation espousing the cause of human liberty" had to take its responsibility in making "the world safe for democracy," Afro-Americans understood it was time for the United States "to set their own house in order." ${ }^{\mathrm{xv}}$ As the world was fighting for freedom for all, the time was ripe for a new day to appear for the people of color of the United States.

10 As a matter of fact, US involvement in World War I created a moral dilemma for many Afro-American women. Though strong pacifists, they advocated the black community's support for the war effort. They used patriotism as a tool to force the Wilson Administration to grant them their denied rights. Yet, the obstacles black soldiers and nurses encountered while serving their country and the harsh racism they faced from their white American counterparts became a duplicate of their everyday life in the United States. First World War battlefields became a microcosm of the American South.

11 Two-African women activists, Addie Hunton and Kathryn M. Johnson, who volunteered to work with African American troops stationed in France, documented the sad experiences of their male counterparts in Europe. ${ }^{\text {xvi }}$ Among their missions while in France, they sought to investigate the shameful treatment of black soldiers by the US government. They felt responsible for promoting racial pride among the soldiers and 
considered themselves to be "crusaders on a quest for democracy." $x v i i$ attended the August 1918 Paris conference of Allied Women. ${ }^{\text {xviii }}$

12 In fact, Addie Hunton had insisted in serving abroad in France because she considered France to be the example of republican democracy. The discrimination against black soldiers she witnessed while in France pushed her to extend her international pan-African commitments. She became one of the key organizers of PanAfrican congresses which sought to attract world attention to the conditions of people of color everywhere in the world. In February 1919, she attended the second PanAfrican Congress in Paris and was at the negotiation table discussing the future of Germany's former African colonies. At this congress, Addie Hunton spoke "of the importance of women in the world's reconstruction and regeneration of today, and of the necessity of seeking their co-operation and counsel...." ${ }^{\text {xix }}$ Such action shows that Afro-American women were determined to change the course of history. In addition, the fact that W.E.B. Du Bois mentions Addie Hunton's speech in his account of the Congress demonstrates that Afro-American women counted in the Pan-African Congress movement.

13 During the peace process negotiations, black women activists did not hesitate to voice their priorities. They wanted to be heard regardless their views. Ida Gibbs Hunt, another Pan-African woman leader, supported the League of Nations she viewed as a viable tool for the promotion of human rights and world disarmament, claiming that America could no longer ignore racial injustice at home while talking about peace with other countries..$^{\mathrm{xx}}$ On the contrary, Mary Church Terrell who is discussed in further details in the next part of this article opposed the ratification of the Treaty of Versailles. She considered the Democratic Party support to the League of Nations as a ruse to obtain the black votes. ${ }^{x x i}$

14 Nevertheless, World War I showed the failures of conventional approaches to international relations and validated the Afro-American women's agenda insofar as it became clear that permanent peace and true freedom could only be achieved on mutual understanding between nations. This leads us to briefly mention the role AfroAmerican women played in the international feminist peace movement. ${ }^{x x i i}$

15 As peace activists, Afro-American women took part in the international feminist peace movement and were active members of organizations like the Women's International League for Peace and Freedom (WILPF) founded in 1915 by Jane Addams. They gradually increased their visibility, their actions, and used these movements to challenge the prevailing discourses on women's issues. While addressing international audiences, they dared to challenge white American women. Their speeches focused on the universality of the women's cause, claiming that the injustice against a class of women was harmful to the general women's movement. Their call for a true democracy insisted on a more inclusive gender perspective. In addition, their black female consciousness brought the issue of race to the feminist peace agenda. The interesting aspect of their involvement in the feminist peace movement rests upon their bold stance within this movement. They brought a new perspective to the movement which placed the question of race at the forefront of domestic and international peace.

16 Nevertheless, even if Afro-American women were very active members in international organizations, they remained on the margins of these movements. Their voices were often muted by the leadership of black men and white women. Yet their relentless activities within these movements show that Afro-American women wanted 
to have a place in the nation and to be a voice for global causes. As they wanted to become the sustaining forces behind the modern movements for democracy and peace, they realized that the best way to achieve their goals was to launch their own initiatives through their own organizations.

\section{Afro-American women as peace promoters and human rights advocates}

17 One way to look at the scope of Afro-American women's role as mediators and negotiators on the international scene is to first examine the missions they set for their own organizations. One common denominator is that from the very beginning, these organizations rooted their activism in international activities and they all took on the challenge to "fight for a better world" by increasing cooperation, reaching out to international networks and advancing a more holistic peace and human rights' agenda. A second step is to look at race women leaders' main contribution to the shaping of innovative peace and human right issues and discourse. As presidents of black female organizations, they all took the responsibility to act as the representatives of the voiceless masses.

\subsection{Black women's organizations}

\subsubsection{The National Association of Colored Women-NACW (1896-)}

18 After they had been excluded by white women from the planning activities of the 1893 World's Fair, black women founded the NACW (National Association of Colored Women) in July1896.xxiii The fact that Afro-American women founded their own organization fourteen years before the creation of the NAACP was set up, shows that they shrewdly understood that Afro American women had a tremendous responsibility and opportunity to speak on their own behalf and offer race leadership. They needed to "band together" against the "barbarities and abuses" degrading black Americans. ${ }^{\text {xiv }}$ Mary Church Terrell, ${ }^{\mathrm{xx}}$ as the founder and first president of the organization, explained the significance of the existence of the NACW in these terms "...we have joined hands one with the other to work together in a common cause. We proclaim to the world that the women of our race have become partners in the great firm of progress and reform." $x x v i$

19 Mary Church Terrell, who studied in France, Germany and Switzerland, was also a very active spokesperson for the National American Woman Suffrage Association. Her trips abroad as a student and then a lecturer shaped her understanding of the "the race problem in the United States." Her organization would be the vehicle through which she could promote the welfare of her race. She was determined to use the international platform as a new venue to inform ${ }^{\text {xxvii }}$ people of the different manifestations of racism in the United States. From its inception, she also gave the NACW a truly international dimension by organizing a Foreign Relations Committee in charge of keeping abreast of world issues.

20 At the fifteenth Convention of the NACW in 1926, Mary McLeod Bethune, xxviii acting then as its eighth president, gave a new dimension to the international scope of the organization. She wanted it to be a clearinghouse that could speak as one voice for the 
interests of all black women to the rest of the world. ${ }^{\text {xix }}$ She clearly reaffirmed the international mission of the organization:

This organization must assume an attitude toward all big questions involving the welfare of the nation, public right and especially the present and future of our race. These questions are both national and international. ... This brings forward the "color question" belting the world...Bred, born and living here under the American Flag, we nevertheless bear a relation to others of our blood. Their problems are ours and vice versa. ... We must make this national body of colored women not merely a national influence, but also a significant link between the peoples of color throughout the world. ${ }^{\mathrm{xx}}$

Mary McLeod Bethune also linked the race issue to international security:

It is my judgment that this great Association is the lever with which to overturn racial intolerance and artificial prejudices. They hinder human unity in America and throughout the world where a deadline has been drawn between the white races and people of colored blood. ${ }^{\mathrm{xxi}}$

22 One year later, in 1927, under the presidency of Mary McLeod Bethune, the NACW organized a nine country European tour, so that Afro-American women could understand national and international politics and widen their visions through contacts made in these foreign countries.In that same year, the fourth Pan African Congress was organized in New York mainly through the effort of the Women's International Circle of Peace and Foreign Relations, a black women's club in New York led by Minnie Pickens, Nina Du Bois, Du Bois's first wife, and Addie W. Hunton, also an active member of the NACW.

23 Their trips abroad showed Afro-American women that race prejudice against colored people was a worldwide reality. Such reality pushed them to start an all-black women international organization which would act as a kind of think tank and would promote race pride and solidarity around the world. Marry Church Terrell and Mary McLeod Bethune were among the 18 founding members of the International Council of Women of the Darker Races of the World.

\subsubsection{The International Council of the Women of the Darker Races-ICWDR} (1922-1940)

24 The International Council of the Women of the Darker Races was mainly founded by Margaret Murray Washington, Booker T. Washington's third wife. The Council's main objective, as stipulated in its constitution, was the "dissemination of knowledge of people of color so that the world can better appreciate their history and accomplishment." "xxiii One of the main priorities set up by the constitution was the study of the history and conditions of women of the darker races throughout the world. Even the committee on education had an international scope. It had to work for the promotion of the literature of the darker races in the schools of the various countries.

25 Though the ICWDR operated for an eighteen-year short-lived period, its symbolic achievements are quite revealing of the visionary outlook of its members. ${ }^{\text {xxxiv }}$ Indeed, the originality of the ICWDR rests upon the fact that, as an elite organization (membership was only open to women who had completed an outstanding piece of work,) $)^{x \times x}$ its members understood the importance of promoting knowledge as a means of uniting people, as a bridge towards a better understanding between people of color and better accommodation between nations. The leaflet distributed to the members of the Council insisted on networking building. Its members, mainly black female leaders, 
were prolific writers and they wrote many articles on global issues and on the status of women around the world. They supported studies on conditions in Haiti, Cuba and India. They were convinced that greater solidarity between non-white groups would in turn generate solidarity in the global struggle against white supremacy.

26 The ICWDR had a strong political orientation and focused on the promotion of world peace. It set up a committee solely dedicated to international relations. The members planned to have a representative in Geneva as it had become the headquarters of the newly-founded League of Nations, with the idea of influencing governmental decision-makers in the peace-building process.xxxvii They attended the World Peace Conference held in Prague in 1929 and had an audience with the Pope ${ }^{\text {xxviii }}$. Some of ICDWR members realized that they needed to influence US foreign policymakers if they wanted to make a difference in the building of a new world. In 1933, during the Liberian crisis, three ICWDR members were part of the WILPF delegation who met with the Assistant Secretary of State, William Philips, to prevent US intervention in Liberia ${ }^{\mathrm{xxx} x}$. Though the influence of the delegation can be debated, the United States did not intervene in Liberia. ${ }^{x l}$

27 In December 1935, one of the founding members of the ICWDR, Mary McLeod Bethune founded a new organization, the National Council of Negro Women. So we can say that indirectly, the ICDWR continued to survive through Mary McLeod Bethune.

\subsubsection{The National Congress of Negro Women-NCNW (1935-)}

28 Mary McLeod Bethune decided to found a new Afro-American women's organization, the National Congress of Negro Women, because she wanted to articulate the action of black women in a federation of national women's organizations. Such an organization would prepare the ground for expansion into a comprehensive international program as it aimed at taking on responsibility for all people who suffered injustice. ${ }^{\mathrm{xli}}$ From its very inception, the NCNW set the tone of its international dimension through the topics of its Annual meetings: The Role of the NCNW in the World Today, the National Defense Round Table, The Role of the Negro Woman in Peace and Time Planning, the Participation of the Negro Woman in the War Effort.

29 Unlike most of her black female counterparts, Mary McLeod Bethune focused her activities on relentless lobbying within the Establishment. ${ }^{\text {xli }}$ She was coined as the "First Lady" of the black community. xliii As a close friend of Eleanor Roosevelt, she could force the official state channels to represent her community. ${ }^{\text {.liv }}$

30 During World War II, Mary McLeod Bethune saw patriotism as a means by which black people could win their citizenship rights as human beings. She was then active in mobilizing support for the war effort among African Americans. She pressured the Secretary of War to commission black women as officers of the Women's Army Auxiliary Corps (WAAC). She also served as Special Assistant to the Secretary of War for the Women's Army Auxiliary Corps, with a five-day mission to recruit black women for army officer training. She led the NCNW's "Buy War Bonds" drive to launch the Harriet Tubman vessel, a US merchant marine Liberty Ship which was built to transport supplies to allied troops overseas. She organized the "We serve America Week" to promote the woman's role in the war history." ${ }^{x l v}$

31 After presenting these three black female organizations, I will now give an overview of some of the key actions undertaken by their leaders. I will examine how their 
interactions across borders and movements fueled their energies and their ideologies, cemented an international collective identity of the darker races, and framed new discourses around human rights and peace issues. Their bold speeches are revealing of the role they wanted to play in the shaping of a new world. They brought issues that mattered to them to the negotiation table. They wanted to play a part, not take a back seat. ${ }^{\text {xlvi }}$ As early as the $20^{\text {th }}$ century, the threat posed by the expansion of the arms industry to the future of democracy and peace, the necessity of a new international order, the end of colonialism, the call for a more holistic global justice agenda, were issues of primary concern to them. Some of these issues are still debated nowadays.

\subsection{Black women leaders as spokespeople of the voiceless}

\subsubsection{Mary Church Terrell}

32 As an active member of the international feminist peace movement, Mary Church Terrell was given the opportunity to speak on behalf of her community at two international women's congresses: in Berlin in 1904 (ICW) and in Zürich in 1919 (IWLPF). At these two events, she decided to give her speeches in fluent German so as to present a new image of what a black woman living in America could be. In Berlin as well as in Zürich, Mary Church Terrell realized that she was vested with a tremendous responsibility as she

represented, not only the colored women of my own country but, since I was the only woman taking part in the International Congress who had a drop of African blood in her veins, I represented the whole continent of Africa too. ${ }^{\text {xlvii }}$

Berlin gave her a good opportunity to debunk the myth of white superiority. Indeed, at this congress, everybody was looking forward to hearing "die Negerin." She wanted to prove that was not the "unusual anthropological specimen" they were seeking. Her speech was given large press media coverage in Europe. While she was in Berlin, she predicted the future problems confronting the world. Indeed, in her autobiography, she compared the situation of Jews living in Germany with that of black Americans and raised the issue of their victim status. From then on, she would constantly warn her audience and readers of the unfair colonial mentality and its brutal politics on "inferior" races.

34 In Zurich, ${ }^{\text {xviii }}$ as she was still acting as the unofficial ambassador of the absent voices, she gave a symbolic speech in which she sought to challenge the ruling powers of the world. She particularly targeted Washington and colonist states when she paid tribute to the colored soldiers' participation in the war effort. She reminded her audience that "the thousands of colored soldiers who had crossed the sea to make the world safe for democracy" had fought a freedom for others which in some sections of their own country they themselves did not enjoy." "xlix She viewed imperialism as a dangerous threat to global peace. She warned the decision-makers in these terms: "You may talk about permanent peace till doomsday, but the world will never have it until the dark races in the world are given a square deal."

35 Speaking on behalf of the dark races in Zurich, Terrell aimed at giving an alternative vision of the world, a vision that would only start to emerge with the creation of the United Nations in 1945. She wrote a bold resolution against "the discriminations, humiliations and injustices perpetrated, not only upon the colored people of the United States, but upon the dark races all over the world." 
36 In 1921, when a German propaganda campaign accused black American soldiers and African soldiers from French colonies of the sexual exploitation of German women, Mary Church Terrell refused to sign the petition framed by the WILPF which called for the removal of the black troops. In a letter dated March 18, 1921, she informed Jane Addams that she would resign, arguing that she could not accept the distorted racial representation of black troops carrying out more assaults than any other race of soldiers, and reminded her how women of her race "have been the victims of assaults committed upon them by men of all races." Following Terrell's appeal for racial justice, the petition was not processed.

37 Two years later, Mary Church Terrell decided to protest against the cable Raymond Poincaré sent the US State Department in which he wrote that only white troops were used in the Ruhr and that black troops from Morocco and Algeria would be barred from participating. She sent a warning letter to Poincaré as she "felt it was my duty to let some of the French officials know how a colored woman in the United States felt about the matter." succumb to the "germ of race prejudice." lii

\subsection{Building bridges: The NCWN and Mary McLeod Bethune}

38 Mary McLeod Bethune's activism is pioneering insofar as some of the initiatives that she launched are more than replicates of the diplomatic tools used by nations: political, cultural and social events were needed to bridge the divide between black and white people. She played the role of mediator.

39 When she launched the NCNW, Mary McLeod Bethune set up an Intercultural Committee which conducted educational and cultural programs with representatives of the governments in the nation's capital so as to improve mutual understanding. She understood the importance of launching cultural and educational initiatives to foster closer relationships. This demonstrates her far-sighted perspective of multilateralism.

40 Bethune also insisted on having headquarters in Washington, with a two-fold objective: to be close to the decision-making sphere and to reach out to women of all nationalities and to ambassadors' wives. She also viewed the headquarters as a place to learn more about the colored people around the world, and as a discussion venue on world affairs. The NCWN was to give black American women visible representation in national and international affairs. To promote such representation, the Aframerican, the official magazine of the NCNW focused, in its editorials, on prospects for world peace and the international status of women.

41 As early as the mid nineteen-fifties, Mary McLeod Bethune institutionalized the international scope of the NCNW by launching a series of events that would help bridge the gap between non-state actors and the official diplomatic body. She gave receptions for ambassadors of the darker continent. ${ }^{\text {liii }}$ In October 1944, she launched the first international session involving personnel from foreign embassies. A new bridge was being built when the two guest speakers, the female ambassador to Norway, Florence Harriman and Mary Church Terrell, delivered their speeches. Governmental and nongovernmental representatives were united around a single voice. Following the success of this event, the NCNW started it yearly International Nights. As an example, the third International Night attracted representatives of more than twenty-five embassies. An article from the Pittsburgh Courier praised the event in the following terms "NCNW 
Program Boosts International Relations." liv In the spring of 1945, Mary McLeod Bethune launched the "World Security Month."

42 She took a bold step when she forced her way into world diplomacy to take part in the building of the new world. Relying on her connection with Eleanor Roosevelt, she lobbied the State Department to take part in the delegation attending the United Nations founding Conference in 1945. Another black female activist, Amy Jacques Garvey, who had until then acted behind the scenes, also seized the founding of the United Nations to stage her intrusion into world politics with her Memorandum Correlative of Africa, the West Indies and the Americas, a protest document she addressed to the UN. Both women, though completely different in their strategies, wanted to show the world that black women had to be negotiators and architects of a better post-war world. Both women wanted to be on the frontlines of the struggle to achieve "democracy for all people."

\section{Afro-American women as crafters of new diplomacy}

43 At this stage of my reflection, I need to draw a quick parallel between Mary McLeod Bethune's advocacy and lobbying work and the emergence of transnational feminism in the United Nations in the post-Cold War era. Bethune's determined and longstanding involvement set an example for the participation of women in American foreign policy more than a half-century before Bella Abzug transformed feminist NGOs into a powerful political force in the United Nations conferences of the 1990s, conferences which gave legitimacy to non-state actors in the making of foreign policy. I argue that Mary McLeod Bethune paved the way to the new diplomacy emerging in the twentyfirst century.

\subsection{Mary McLeod Bethune at the negotiation table of the founding conference of the United Nations.}

44 For Bethune, the end of World War II meant a new day. The United Nations was to model the new world, so the time was all the more ripe for her presence at the negotiation table. Even before her selection, she claimed that "African Americans will be sitting at the peace table, if only in spirit." American women had been pushing for a half-century turned out to be at the top of the agenda at the official negotiations of the founding conference of the United Nations which was held in San Francisco in 1945.

45 Out of a total of 126 consultants officially selected by the US State Department to assist the seven-member American delegation, ${ }^{\text {lvi }}$ Mary McLeod Bethune was among the three NAACP representatives. With W.E.B. Du Bois, she acted as advisor to Walter White who was then the executive secretary of the organization. "vii She was the "only dark woman of the world who was an official representative." "viii In this position, she could lobby delegates, officially and informally, to push various issues forward at the negotiation table, among which the abolition of colonialism, the adoption of an international bills of rights, the inclusion of the masses of people of all countries in UN projects, the right of all people to be represented in a world organization and the rights of women. This was no easy task. 
46 At first, Mary McLeod Bethune strongly lobbied the State Department to have the NCNW be part of the advisor delegation, arguing that her organization represented more than twenty black women's organizations, and more specifically around six and a half million black women. She openly wanted to force the male world of international politics and diplomacy. The letter sent by Du Bois to Bethune on April 30, 1945 shows that she was achieving her goal. In that letter, Du Bois wanted to have Bethune's reaction regarding a resolution he drafted and to be discussed before the American delegation. The resolution concerned the role of darker races in the framing of international and durable peace. In this resolution, Du Bois explained that the darker peoples of the world could no longer be reckoned as a numerical minority. ${ }^{\text {lix }}$ In the June 1945 issue of the Aframerican Women's Journal, Bethune stressed the importance of black women's presence at the founding of the UN conference. She advocated that black women should be considered more than just women, more than just blacks. They should be considered as international ambassadors for human justice. Because of her black female consciousness, Mary McLeod Bethune felt she was responsible for representing all women of color. To make black women even more visible at the founding event, she sent three more NCNW members as observers. ${ }^{1 x}$

47 In her open letter/speech on the San Francisco Conference, in which she explains the nature, scope and significance of the conference and the United Nations in regard to black and "Third World" people, she clearly explains her role :

I'm here as one of the three Negro consultants to the US delegations to the UN conference, appointed by the US department of State... channeling to the delegates of every nation the wishes and aspirations of the masses in order that they may be inculcated into the structure of international planning. ${ }^{\text {lxi }}$

In this letter, just as Mary Church Terrell in Berlin in 1904, Mary McLeod Bethune also predicted the two key problems at the forefront of the international agenda: colonial problems and human rights for all people.

49 The interesting point at this founding conference is that the NCNW members foresaw the necessity for a new world order. In her article in the Chicago Defender of April 16, 1945, Sue Bailey Thurman, who headed the informal NCNW delegation, raised the looming issues confronting the international organization. She pondered the prominent role of the big Five and the absence of the large population from the darker races. ${ }^{\text {.xii }}$ Through her reflection, she pointed out the fact that Third World countries would play a significant role in the future of the organization.

50 As for Mary McLeod Bethune, she concluded that the darker races could "no longer be reckoned as a numerical minority."|xiii Therefore, she boldly challenged Washington by requesting that

America itself must do a great deal of housecleaning in its treatment of the Negro here within its own borders before democratic ideals of human rights can be adequately projected from our viewpoint into this world program of freedom and brotherhood. lxiv

51 Mary McLeod Bethune rated her experience at the United Nations as one of the greatest opportunities of her life as she was contributing to the engineering of peace for all people and to the building of a new and better world. After her five-week attendance at the UN founding conference, she pursued her reflections on US foreign policy and often took the initiative to share her vision of diplomacy with the Establishment acting as an informal advisor. 
52 When in January 1949, President Truman launched his Four Point Program, a technical assistance program for developing countries, she addressed a letter to the Secretary of State Dean Acheson, in which she argued that her organization felt "a special responsibility in submitting suggestions to the Department for the formulation and execution of policies." ${ }^{\text {xv }}$ She warned the Secretary of State of the necessity to carry out projects in the primary interest of the peoples of the territories concerned and not for strategic purposes.

53 She seized upon Dean Acheson's "impressive concept of total diplomacy" to advance her agenda, to give a voice to the people of the darker races. What was Bethune's definition of total diplomacy? In that same letter, she explained to Dean Acheson that the successful application of his concept depended on him appointing the right people, pointing out "inasmuch as most of the peoples living in the underdeveloped territories are colored, I strongly feel that competent Negro Americans should be appointed to Advisory boards, special committees and joint commissions." She even pushed for fairer gender representation. ${ }^{1 \times v i}$ She added that she was ready to provide him with a list of competent people. She even suggested that it was possible for her "to come in and talk with you in the very near future about our interest in the entire Point Four Program."

54 The many columns that McLeod Bethune wrote in the Chicago Defender also shed light on her vision of diplomacy. ${ }^{\text {Ixvii }}$ In a 1950 article, Mary McLeod Bethune stated that even if she knew very little "about the formalities of statescraft we call diplomacy," even if she considered herself as not vested in this domain, she was sure

that America's failure to understand the concept of brotherhood was leading to disaster. America was to recognize the possibilities that there are other ways of thinking than hers and that the race superiority concept is misleading in domestic and international affairs.

She advocated that "along with the State Department and the Defense Department, there was also a Department of Human Relations devoted to the task of applying the doctrine of Brotherhood of Man." "1xviii

56 In another article, she commented on the fact that her view of diplomacy corresponded to that of John Foster Dulles. Quoting his book "War or Peace" (1950), she reminded Americans that "We must not forget that we are only one nation among sovereign equals." $x$ xix From its inception, her organization (the NCNW) had advocated "fair and equal considerations for the rights of all nations, large and small."

57 Lastly, as we saw previously, like most of her contemporary counterparts, her view on diplomacy encompassed an intellectual component: knowledge as a tool "to open the doors between the peoples" with the view of stimulating discussion and thinking. American race leaders considered that it was vital to be watchful of trends, conscious of the realities of the world. ${ }^{\text {lxxi }}$ They wanted their organizations to act as think tanks for the darker races. Most women race leaders were prolific writers. In particular, Amy Jacques Garvey used her writings as a tool both to protest and to disseminate information.

\subsection{Amy Jacques Garvey: the UNIA "Joan of Arc"}

58 Unlike the race leaders I have discussed in this article, Amy Jacques Garvey, Marcus Garvey's second wife, dedicated her whole life to promoting her husband's ideas and 
organization. As the UNIA's secretary, she held a key position in the organization and acted as Garvey's ambassador during his numerous incarcerations. Ixxii She was hailed the "Joan of Arc" of UNIA by its members, in recognition of her behind-the-scene leadership. ${ }^{\text {Ixxiii }}$ After World War I, the broken promises of a true democracy led to the unprecedented mobilization of black Americans and the UNIA emerged as one of the largest black organizations in the United States, with a membership of six million in 1923. The redemption of Africa from European colonists, the creation of an African empire and the establishment of an international black economy were among the many objectives set by Garvey. Garveyism helped to advance the political consciousness of blacks worldwide and to promote racial pride.

59 As a journalist and editor, Amy Jacques Garvey developed her ideas on feminism and international ideas. In Negro World considered the ideological arm of the UNIA, she created a woman's page "Our Women and What they Think" from 1924 to 1928. The woman's page ran articles from home life to war, domestic and international women's struggles and achievements. Her many articles in Negro World insisted on the importance of educating black women about foreign affairs and highlighted her competent grasp of international political issues. She was interested in the "worldwide movement for the enlargement of women's sphere." "|xxiv Her numerous travels with her husband widened her understanding of world politics. She articulated a strong position against colonialism. Just like the ICDWR, the UNIA gave strong emphasis to the study of black history, viewing knowledge as a weapon against imperialism. Amy Jacques Garvey regarded sharing written information as a powerful form of resistance. In addition, racial solidarity was seen as an effective means to put an end to colonialism and solve the race problem. The Garveys turned to the League of Nations which they considered as the necessary influential body to settle conflict, like the invasion of Ethiopia by Italy in 1935.

60 In this article, I mainly examine, what Amy Jacques Garvey considers one of her key achievements in foreign policy, her Memorandum Correlative of Africa, the West Indies andthe Americas Sent To The Representatives of the United Nations. The sixty-six page document is a critical analysis of the eight points of the Atlantic Charter which was drafted by President Roosevelt and British Prime Minister Churchill in August 1941. It is a policy statement expressing their views on peace and international security after the world conflict and focused mainly on the "oppressed nations of Europe." The Charter was agreed on by all the Allies in January 1942. In her memorandum, Amy Jacques Garvey critiques the Eurocentric aspect of the Charter and questions its implementation, ${ }^{1 \times x v}$ and she gives an overview of the main contributions of Africans to civilization.

61 One section of the Memorandum dealt with the race issues in the United States focusing on "the devious forms of discrimination" approved by the Government. ${ }^{\text {lxxi }}$ The last part of the section advocates solutions to solve the race problem in the United States and urges the President of the United States to take immediate action.

62 She pleads for an International Charter for Africa which would grant any black person from any region including the United States the same right as any white citizen, and for an African Freedom Charter which would give all peoples of African descent their share of democracy. Ixxvii

63 As a matter of fact, the memorandum is the result of collaborative work carried out by an umbrella of Pan-African organizations. ${ }^{\text {lxviii }}$ Amy Jacques Garvey was the sole 
initiator of this enterprise and orchestrated the work from Jamaica. She conceived of the collective protest writing as a means to theorize and popularize Pan-African demands. Through Adam Clayton Powell Jr, one of the editors of the People's Voice, she framed the main objectives of the memorandum and suggested its contents. She then targeted a number of contacts requiring them to return their individual memorandums to her. She intended to give a more comprehensive view of Pan-African demands and African Nationalism.

64 Amy Jacques Garvey merged the multiple memorandums into one single document which she typed on her own for four months. As the memorandum was to be the worldwide representation of Pan-Africans to world leaders and as she wanted to give it authoritative power, she refused any personal reflection to appear in the document. However, she avoided the use of the term Negro, because of its pejorative meaning in her view, depreciating the status of African Americans and conveying Eurocentric race superiority. She considered that the choice of language register used had political significance.

65 This memorandum can be considered as a pioneering advocacy tool used in the United Nations. Amy Jacques Garvey coordinated the different steps of its drafting and ensured that the document reached the decision-makers, the heads of states of the Big Five. Like Mary McLeod Bethune, she became an inspirational model for NGO advocacy and lobbying in the United Nations. The Woman's Caucus, launched by Bella Abzug in the post-1990 population and women conferences of the United Nations, was a modern version of Amy Jacques Garvey's Memorandum. Amy Jacques Garvey's contribution to women's history and transnationalism needs to be further investigated.

\section{Conclusion}

66 It seems to me that Hillary Clinton's concept of smart power redefines the informal diplomacy pushed by Afro-American women leaders since the early twentieth century. Hillary Clinton defines smart power as the full range of tools at the disposal of the State Department, in particular diplomatic, political and cultural tools, to advance the broad arrays of goals. She argues that “... building these coalitions, spurring initiative ... around the world, using people to people exchanges is actually the core of smart power." "Ixxix It seems that such definition embodies Afro-American women's internationalism.

67 Afro-American women, through their wide-ranging interests and involvement their trips abroad, their seminars, their platform lectures, their publications, their resolutions and speeches, showed that diplomacy was not only the domain of the State. We can say that they forced the traditional channels of diplomacy and challenged the government primacy in agenda-setting to show that other options were possible and more suitable in terms of race issues. By usurping conventional approaches to diplomacy, their parallel informal networking and protests aimed at remodeling American society and building a better world. They acted as "real powers for good."

68 As Afro-American women looked at the world from the standpoint of their particular experiences, they offered a multi-layered stance on the meaning of peace. The rise of Afro-American women (Ida B. Wells, Mary Church Terrell, Addie Hunton, Mary McLeod Bethune and Amy Jacques Garvey) to prominent leadership positions as justice and human rights advocates on the international stage in the late nineteenth 
century and early twentieth century is deeply interconnected to their female black consciousness. While pursuing the constitutional rights of citizenship for black Americans, they broadened their fight to include all colored people in the world. Their international activism helped them conceive of a more global agenda around peace and human rights issues. They took on the challenge to debunk the euro-centric discourse of racial superiority to "pursue a true and unfettered democracy." not only for their community's equal rights, but also for a more inclusive human rights agenda.

69 They defied the status quo of white supremacy and built networks to legitimize their voices. Not only did they reveal to the world the reality of "the cruel-hindered group of human-beings in the greatest Republic on earth,"lxxxii they also articulated positions against oppression, colonialism and became proponents for selfdetermination.

70 Afro-American women leaders played the role of representatives of the darker races, acting as bridges between whites and blacks, between citizens and governments. Race women leaders played a pivotal role in promoting transnationalism and thus forced their intrusion into the world of diplomacy.

\section{BIBLIOGRAPHY}

\section{$\underline{\text { Public Papers }}$}

Mary McLeod Bethune (Harvard Library)

Reel 1, part 2

Reel 2, part 1

Reel 4, part 2

Reel 9, part 1

Reel 12, part 2

Mary Church Terrell (Harvard Library)

Reel 14

Reel 21

Journals/Newspapers

Du Bois, W.E.B. “The Pan African Congress”. Crisis. April 1919.

The Chicago Defender. Issues:

December 2, 1948

August 12, 1950

November 25, 1950 
December 15, 1951

Clinton, Hillary Rodham. "Smart Power". Speech at the Council of the Foreign Relations. US Department, July 15, 2009.

Duster, Alfreda. Crusade for Justice, the Autobiography of Ida B. Wells. Chicago: The University of Chicago Press, 1970.

Garvey, Amy J. Memorandum Correlative of Africa, the West Indies andthe Americas Sent To The Representatives of the United Nations. Jamaica, 1944 (Houghton Library - Harvard).

Hanes, Walton Jr. Black Women and the United Nations, The Politics, A Theoretical Model, and the Documents. San Bernardino, California: The Borgo Press, 1995.

Hanson, Joyce Ann. Mary McLeod Bethune and Black Women's Political Activism. Columbia, Missouri: University of Missouri Press, 2003.

Hunton, Addie and Johnson, Kathryn. Two Colored Women with the American Expeditionary Forces. New York: Brooklyn Eagle Press, 1920.

Materson, Lisa G. “African American Women's Global Journeys and the Construction of CrossEthnic Racial identity”. Women's Studies International Forum. Volume 32. Issue 1 (2009): 35-42.

Mc Cluskey, Audrey Thomas and Smith, Elaine. Mary McLeod Bethune: Building a Better World, Essays and Selected Documents. Bloomington: Indiana University Press, 1999.Rackham, Holt. Mary McLeod Bethune: A Biography. New York: Doubleday. 1964.

Rief, Michelle. "Banded Close Together": An Afrocentric Study of Afro-American Women's International Activism, 1850-1940 and the International Council of Women of the Darker Races. Doctoral dissertation: Temple University, 2003.

Smith, Elaine. Mary McLeod Bethune and the National Council of Negro Women, Pursuing a True and Unfettered Democracy. Alabama: Alabama State University, 2003 - Historic Resource Study for the Mary McLeod Bethune Council House.

Taylor, Ula Yvette. The Veiled Garvey: The Life and Times of Amy Jacques Garvey. Chapel Hill, North Carolina: The University of Carolina Press, 2002.

Terrell, Mary Church. Speech and Resolution Presentd at International Woman's Congress, Zurich, 1919, in German and French. Speeches and Writings, 1900-1920 by Mary Church Terrell. Alexandria, VA: Alexander Street Press, 2010.

Terrell, Mary Church. Black People and Arguments by Democrats in favor of the League of Nations. October 26, 1920. Providence 26, 1920. Mary Church Public Papers. Reel 21. Library of Harvard. Terrell, Mary Church. A Colored Woman in a White World. New York: Humanity Books, 1940. White, Deborah Gray, Too Heavy A Load, Black Women in Defense of Themselves. New York: W.W. Norton \& Company, 1999.

\section{NOTES}

i. Black women's contribution to black American history and to US history in general had been relegated to the margins. It is only in the last 30 years that that the history of black Americans has been addressed compared to the history of black men or white women.

ii. Quotation from Mary Mc Leod Bethune (Smith, 2003,8) 
iii. Michelle Rief, "Banded Close Together": An Afrocentric Study of Afro-American Women's International Activism, 1850-1940 and the International Council of Women of the Darker Races (Doctoral dissertation: Temple University, 2003), 67.

iv. After the end of slavery, first-generation families took the initiative to educate their daughters and instill in them a sense of duty to their race.

v. Joyce Ann Hanson, Mary McLeod Bethune and Black Women's Political Activism (Columbia, Missouri: University of Missouri Press, 2003), 24.

vi. Yet, no African American woman is known to have participated in the 1840 World AntiSlavery Convention held in London or in the 1848 Seneca Falls Convention at which Frederick Douglass gave a speech.

vii. Deborah Gray White, Too Heavy A Load, Black Women in Defense of Themselves (New York: W.W. Norton \& Company, 1999), 137.

viii. Lisa G. Materson, “African American Women's Global Journeys and the Construction of Cross-Ethnic Racial identity”, Women's Studies International Forum, Volume 32, Issue 1 (2009): 37-38. ix. Ida B. Wells (1862-1931) was born a slave in Holly Spring (Mississippi). She became an orphan at the age of 16 and took a teaching position to support her family. She began writing for the Negro Press Association. She was an outspoken crusader against racial injustice and lynching. As a woman's rights advocate, she was actively involved in numerous Afro-American women's organizations.

x. Ida B. Wells, the anti-lynching crusader, was among the founders of the NAACP. However, her name is not mentioned in the list of the founding members. In her autobiography, Wells complains that Du Bois deliberately excluded her from the list, while Du Bois claims that Wells had chosen not to be included.

xi. Alfreda Duster, Crusade for Justice, the Autobiography of Ida B. Wells (Chicago: The University of Chicago Press, 1970), 130-131.

xii. Mary Talbert Burnett also toured eleven European countries to educate European people on the conditions of black Americans in the United States.

xiii. Duster, Crusade for Justice, 189

xiv. Ibid.,117.

xv. Mary Church Terrell, Speech and Resolution Presented at International Woman's Congress, Zurich, 1919, in German and French. Speeches and Writings, 1900-1920 by Mary Church Terrell (Alexandria, VA: Alexander Street Press, 2010).

xvi. These two African American women activists spent fifteen months with black soldiers in France. Another black woman Helen Curtis was also sent to France to administer support services for Afro-American soldiers.

xvii. Addie Hunton and Kathryn Johnson, Two Colored Women with the American Expeditionary Forces (New York: Brooklyn Eagle Press, 1920), 11-12, 23.

xviii. Hunton and Johnson, Two Colored Women, 221.

xix. W.E.B. Du Bois, “The Pan African Congress”, Crisis, April 1919:273-274.

Xx. In the paper "The Colored Races and the League of Nations" she presented at the 1923 panAfrican Congress in London, Ida Gibbs Hunt called for the appointment of black representatives in the League and advocated world disarmament.

xxi. Mary Church Terrell, Black People and Arguments by Democrats in favor of the League of Nations. October 26, 1920. Providence 26, 1920. Mary Church Public Papers. Reel 21. Library of Harvard.

xxii. In her dissertation, No Peace Without Freedom, No Freedom Without Peace: Afro-American Women Activists in the Women's International League For Peace And Freedom, 1915-1970 (1998), BlackwellJohnson Joyce analyses thoroughly the black women's activism and influence on the international feminist peace movement.

xxiii. The motto of the organization was "Lifting as we Climb". 
xxiv. Mary Church Terrell, "The duty of the National Association of Colored Women to the Race", in Published Speeches and Writings, 1888-1953 (Alexandria, VA: Alexander Street Press, 2010), 340-354.

xxv. Mary Church Terrell (1863-1954) was born during the Civil War to a wealthy family in Memphis, Tennessee on September 23, 1863. She was one of the first African American women to be awarded a college degree (Oberlin College). Terrell was appointed to the District of Columbia Board of Education in 1895. She was the founder of National Association of Colored Women. She became involved in many women's organizations and was a charter member of the NAACP.

xxvi. Mary Church Terrell, "In Union, there is Strength, 1897, http://www.blackpast.org/1897mary-church-terrell-union-there-strength\#sthash.zpkIPUKg.dpuf, downloaded November 16, 2013.

xxvii. In her autobiography, she uses the phrase "enlighten the people of Europe" when she discusses the 1919 Zurich International Women's Conference for Permanent Peace.

xxviii. Mary McLeod Bethune was born in Mayesville, South Carolina as the child of former slaves. She graduated from the Scotia Seminary for Girls in 1893. Believing that education provided the key to racial advancement, she founded the Daytona Normal and Industrial Institute in 1904, which later became Bethune-Cookman College. Bethune also became involved in government service, lending her expertise to several presidents. In 1935, she became a special advisor to President Roosevelt on minority affairs, her most significant role in public service. That same year, she founded what has become since then the largest black women's organization, the National Council of Negro Women.

xxix. Hanson, Mary McLeod Bethune, 107.

xxx. Audrey Thomas Mc Cluskey and Elaine Smith, Mary McLeod Bethune: Building a Better World, Essays and Selected Documents (Bloomington: Indiana University Press, 1999), 161.

xxxi. Mc Cluskey, Mary McLeod Bethune, 162.

xxxii. The Congress gathered 208 delegates from the United States and ten foreign countries, including the Gold Coast, Sierra Leone, Liberia, and Nigeria. http://exhibitions.nypl.org/ africanaage/essay-pan-africanism.html, downloaded on November 16, 2013.

xxxiii. Mary Church Terrell Public Papers, Reel 14, Constitution of The International Council of Women of the Darker Races.

xxxiv. In 1929, the ICDWR had 41 members of American nationality and less than a half-dozen members from other nations.

xxxv. ICWDR had three presidents over the course of its eighteen-year history: Margaret Murray Washington (1922-1925), Addie Hunton (1925-1928), and Addie Whiteman Dickerson (1929-1940). Most of the members of the ICDWR were involved in several other organizations and were unable to participate in all the activities of the Council. When Dickerson died in 1940, the Council disappeared as no new volunteer took up the work of the group.

xxxvi. Rief, Banded Close Together, 219.

xxxvii. Ibid., 200.

xxxviii. The ICWDR delegates to the World Peace Conference in Prague were Addie Hunton and Addie Dickerson, who were also active in the Women's International League for Peace (WILPF).

xxxix. Addie Hunton, Addie Dickerson and Nannie Burroughs were the 3 delegates who met the Assistant Secretary of State.

xl. Rief, Banded Close Together, 215.

xli. Elaine Smith, Mary McLeod Bethune and the National Council of Negro Women, Pursuing a True and Unfettered Democracy (Alabama: Alabama State University, 2003), 184. Historic Resource Study for the Mary McLeod Bethune Council House.

xlii. Holt Rackham, Mary McLeod Bethune: A Biography (New York: Doubleday, 1964), 197.

xliii. Bethune has been immortalized in a bronze sculpture in the US capital since1974. It became the first statue on federal soil to honor either an African American or a woman. 
xliv. Roosevelt appointed her to the National Youth Administration's Division of Negro Affairs in 1936. She helped bring together a group of African Americans in the informal Federal Council on Negro Affairs, the "black cabinet" that advised Roosevelt on the issues of black Americans.

xlv. Smith, Mary McLeod Bethune, 178-180.

xlvi. White, Too Heavy A Load, 139.

xlvii. Mary Church Terrell, A Colored Woman in a White World (New York: Humanity Books, 1940), 238-247, 372.

xlviii. It is also worth mentioning that Mary Church Terrell was among the only fifteen American delegates who were granted passports by the US State Department. At first, the International Council of Women had planned to send 30 delegates to the Women's Peace Congress.

xlix. Terrell, A Colored Woman, 375.

1. Ibid., 403.

li. Ibid. , 406-407.

lii. In her autobiography, she explains that she never received a reply to her letter.

liii. She invited ambassador JD Charles from Haiti (JD Charles) and Mr King from Liberia. In 1949, she visited Haiti where she received the highest award, the Order of the Star of America. In 1950, she attended the second inauguration of Liberian President William V.S Tubman.

liv. Smith, Mary McLeod Bethune, 238-239.

lv. Mary McLeod Bethune, "Free World". October 30, 1943, Reel 2, Part 1. Mary Mc Leod Bethune Public Papers (Harvard Libray).

lvi. Forty-two national organizations were officially selected to send 3 representatives each.

lvii. Du Bois and White reluctantly approved of McLeod Bethune's selection. They considered that she lacked experience.

lviii. Mary McLeod Bethune, Notes from UNCIO (no title), Reel 9, Part 1. Mary McLeod Bethune Papers, Harvard Library.

lix. Letter By W.E.B. Du Bois to Mary McLeod Bethune, April 30, 945, Mary McLeod Public Papers. Reel 4, part 2, Harvard Library.

lx. Sue Bailey Thurman was selected to serve as the head of the NCNW delegation (she was then responsible for the International Relations Committee and founding editor of the Aframerican Women's Journal. She was assisted by Dorothy B. Ferebee, an international medical physician and Eunice Hunton Carter, an attorney.

lxi. Mary McLeod Bethune, May 1945.

lxii. Walton Hanes Jr., Black Women and the United Nations, The Politics, A Theoretical Model, and the Documents (San Bernardino, California: The Borgo Press, 1995), 21.

lxiii. Hanes, Black Women, 52.

lxiv. Ibid., 52.

lxv. Letter from Mary McLeod Bethune to Dean Acheson, Secretary of State, June 30, 1950, Mary McLeod Bethune public papers, Reel 1, part 2

lxvi. Ibid. The letter stipulated "In the execution of the concept, may I suggest that there shall be no discrimination in the selection, training and appointment of persons because of race, language and sex".

lxvii. Founded in 1905, this weekly newspaper was intended primarily for African-American readers.

lxviii. Mary McLeod Bethune, «Diluted Brotherhood Unsucessful When Dealing With Fellow Nations », Chicago Defender, November 25, 1950, p 6 (ProQuest Historical Newspapers).

lxix. Mary McLeod Bethune, "John Foster Dulles Words should help take the Jungle out of Our Diplomacy”, Chicago Defender, December 15, 1951, p 10 (ProQuest Historical Newspapers).

lxx. Mary McLeod Bethune, "Candle Lighted on December 5, 1935 Burns With Growing Brightness » », Chicago Defender, December 25, 1948, p 6 (ProQuest Historical Newspapers). 
lxxi. Mary McLeod Bethune, «Life Itself Must Be Pooled For Peace In A Free World", Chicago Defender, August 12, 1950, p 6 (ProQuest Historical Newspapers).

lxxii. Ula Yvette Taylor, The Veiled Garvey: The Life and Times of Amy Jacques Garvey (Chapel Hill, North Carolina: The University of Carolina Press, 2002), 51.

lxxiii. Taylor, The Veiled Garvey, 3.

lxxiv. White, Too Heavy A Load, 139.

lxxv. Amy Jacques Garvey was informed of the Atlantic Charter by Eleanor Roosevelt when the latter, gave a press conference on a visit to Jamaica in March 1944.

lxxvi. Memorandum, 56

lxxvii. Memorandum, 7

lxxviii. Taylor, The Veiled Garvey, 160-164.

lxxix. Hillary Rodham Clinton, "Smart Power", Speech at the Council of the Foreign Relations, US Department of State, July 15, 2009.

lxxx. Mary McLeod Bethune used this phrase in the singular (power for good) to talk about the accomplishment of her organization, the NCNW.

lxxxi. Taken from the preamble of the Constitution of the National of Congress of Negro Women (NCNW) founded in 1935 by Mary McLeod Bethune.

lxxxii. Mary Church Terrell, Speech and Resolution Presented at the International Women's Congress, Zurich, 1919, in "Speeches and Writings, 1900-1920", downloaded from Black Women Writers, Alexander Street Press, 2010.

\section{ABSTRACTS}

This article demonstrates Afro-American women's pivotal role in promoting transnationalism in the world of politics. It invites us to follow them on their journey to international congresses from the mid- $19^{\text {th }}$ century to the founding of the United Nations. By looking at some personal trajectories of some Afro-American international activists, like Mary Church Terrell, Mary McLeod Bethune and Amy Jacques Garvey, and analyzing some of their speeches, we will try to demonstrate to what extent these women gave legitimacy to the unheard claims of colored people and as such paved the way to modern diplomacy.

\section{INDEX}

Keywords: Black feminism and internationalism, Black women and diplomacy., Black women and human rights, black women and peace, Black women and world politics, Race issues and international politics

Mots-clés: Adam Clayton Powell Jr, Addie Hunton, Amy Jacques Garvey, Bella Abzug, Booker T. Washington, Catherine Impey, Dean Acheson, Eleanor Roosevelt, Florence Harriman, Frances E. W Harper, Franklin D. Roosevelt, Frederick Douglass, Harriet Tubman, Harry Truman, Hillary Clinton, Ida Barnett Wells, Ida Gibbs Hunt, Jane Addams, John Foster Dulles, Kathryn M. Johnson, Marcus Garvey, Margaret Murray Washington, Mary Church Terrell, Mary McLeod Bethune, Minnie Pickens, Nina Du Bois, Raymond Poincaré, Sue Bailey Thurman, Thomas Moss, W.E.B. Du Bois, William Philips, Winston Churchill, Woodrow Wilson 


\section{AUTHOR}

\section{FATMA RAMDAN}

101, rue Yves Decugis, 59650 Villeneuve d'Ascq, France ; ramdanifat@hotmail.com 